\title{
Coping with Exit, Evasion, and Subversion in EU Law
}

\author{
Mark Dawson ${ }^{\star}$
}

\section{A. Categorizing the Challenge of Exit}

In identifying challenges for the EU and EU law in the 2020s, a whole host of topics and questions present themselves. Like any legal order, EU law has to keep pace with its surrounding environment, developing knowledge and tools to deal with new regulatory challenges. What, however, if the EU order's biggest future challenge is also its original one? As I will argue in this short Article, that challenge is fundamentally one of relevance, that is, of maintaining EU law's rule-making and adjudicative capacity in the face of existential threat. The challenge in this sense is to maintain the legacy of the immediate post-founding moment, within which EU law became a relatively autonomous and effective legal order. I will posit this as three challenges - of exit, evasion, and subversion.

Exit is simple departure. As Carlos Closa observed, by making a provision under Article 50 for the exit of Member States from the Union, the EU formalized, and even made respectable, the outright redundancy of EU law for certain states. ${ }^{1}$ This exit can be absolute-the Brexiteer notion of a no-deal Brexit under conditions of high regulatory divergence-or partial—for example, the exit of states from certain areas of EU law ${ }^{2}$ or the decision of third states integrated in elements of EU law to become less integrated. Evasion is much more nuanced. States may decide to turn their backs on EU law without turning their backs on the EU order as such - they may even seek more integration but do so outside of EU law categories. Examples in this basket include the use of international law to regulate relations between EU states, ${ }^{3}$ the increasing development of regulation through guidelines and other forms of soft law, ${ }^{4}$ and the channeling of EU authority through expert institutions in which judicial review is formally possible yet practically difficult to operationalize. ${ }^{5}$ The final category, subversion, is to formally accept EU law and participate in EU decision-making, but to undermine its foundations, either through refusal to comply, or through eroding domestic structures necessary to provide EU law with practical force. The refusal of Member States-often for important constitutional reasons - to comply with enforcement proceedings or preliminary rulings, ${ }^{6}$ and the persistent questions regarding judicial independence in a number of states, ${ }^{7}$ fall into this basket.

\footnotetext{
${ }^{*}$ Professor of European Law and Governance and Delors Institute Research Fellow at the Hertie School of Governance. His research focuses on the relationship between law and policymaking in the EU, particularly in the fields of economic governance and human rights protection. This research has been supported by funding from the European Research Council under the European Union's Horizon 2020 research and innovation programme (grant agreement no. 716923).

${ }^{1}$ See generally Carlos Closa, Interpreting Article 50: Exit, Voice and ... What About Loyalty?, in SECESSION FROM A Member State and Withdrawal from the European Union 187 (Carlos Closa ed., 2017).

${ }^{2}$ See, e.g., Funda Tekin, The Area of Freedom, Security and Justice: Brexit Does Not Mean Brexit 6 (2017).

${ }^{3}$ See generally Bruno de Witte \& Thibault Martinelli, Treaties Between EU Member States as Quasi Instruments of EU Law, in EU Legal Acts: Challenges and Transformations 157 (Marise Cremona \& Claire Kilpatrick eds., 2018).

${ }^{4}$ See generally Päivi Leino \& Tuomas Saarenheimo, Discretion, Economic Governance and the (New) Political Commission, in EU Executive Discretion and the Limits of LAW 132 (Joana Mendes ed., 2019).

${ }^{5}$ See, e.g., Niamh Moloney, The European Supervisory Authorities Beyond Meroni, in EU EXECUTIVE DISCRETION AND THE LimiTs OF LAW 85-94 (Joana Mendes ed., 2019).

${ }^{6}$ See generally Andreas Hofmann, Resistance Against the Court of Justice of the European Union, 14 INT'L J. CONST. L. 258 (2018).

${ }^{7}$ Rule of Law, RECONNECT, https://reconnect-europe.eu/tag/rule-of-law/ (last visited Oct. 23, 2019).
} 
The danger from these three categories, cumulatively speaking, is two-fold. The first danger is that they threaten to unravel the virtuous circle established by the original paradigm of integration through law. That circle was based on a mutually supportive relationship between legal authority and political trust. As Member States became more and more bound to, and integrated within, the EU legal order, so their confidence grew that their internalization of costs associated with integration would be met with similar efforts by other states, thus allowing the EU to deliver collective goods. ${ }^{8}$ The danger, in this sense, is of an erosion of this trust. In the case of evasion for example, why should I, as Government X, deal with refugees using EU law standards, if I observe Government $\mathrm{Y}$ deporting refugees to a third state through a more favorable side-deal arranged on a bi-lateral basis?

The second danger is that these categories inhibit us from dealing with integration through law's many pathologies. One pathology, for example, has been a persistent complaint, both that the EU legal order is too uniform and homogenizing, ${ }^{9}$ and that it precludes opportunities for democratic contestation and involvement. ${ }^{10}$ While exit could be seen as an attempt to tackle homogeneity, as will be elaborated below, it may be precisely the temptation of states-and of EU actors themselves - to exit EU laws that lower incentives to improve and democratize the order-by making that order temporary and contingent, rather than a long-term enterprise that must be made to work for all its participants.

The next section will expand upon this argument by returning to Hirschman's famous distinction between exit, voice, and loyalty, re-visiting Joseph Weiler's application of these categories to EU law in light of recent developments. The final section will consider how EU law might arm itself to deal with the conundrum exit, evasion, and subversion creates.

\section{B. Re-visiting Exit, Voice, and Loyalty}

Hirschman's 1970 classic is only around 160 pages long. ${ }^{11}$ It had, however, an enduring legacy across disciplines. Its familiarity to international relations, and to EU studies more specifically, owes much to Joseph Weiler's use of Hirschman to explain the development of the EU order. ${ }^{12}$ Hirschman described consumers in a product market as engaging with firms in two main ways: When faced with dissatisfaction, they could either opt simply not to buy a product anymore-exit - or they could seek to criticize and improve the product-voice. The latter was more likely in circumstances of loyalty, that is, of a long-term attachment between consumers and brands, which would likely delay the switch to alternatives.

As Weiler realized, Hirschman had provided a brilliant heuristic for developing a general theory of international organizations. There was, Weiler argued, an intrinsic relationship in organizations like the EU between exit and voice. ${ }^{13}$ Higher exit costs increased claims-this time on the part of states-for voice, just as more voice reduced the likelihood of exit. The significance of Van Gend and Costa lay in their foreclosing of exit options. With the advent of supremacy and direct effect, "selective exit," that is, the dis-application of unhelpful EU law provisions, became more and more difficult, encouraging the Member States to increase their influence over EU

\footnotetext{
${ }^{8}$ See generally Joseph H. H. Weiler, The Transformation of Europe, 100 YALE L.J. 2403 (1991).

${ }^{9}$ See generally The End of the Eurocrats Dream: Adjusting to European Diversity (Damian Chalmers, Markus Jachtenfuchs \& Christian Joerges eds., 2016).

${ }^{10}$ See generally Damian Chalmers, The European Union and the Restoration of Democratic Authority, in EUROPE AND THE People: Examining the EU's Democratic Legitimacy 11 (Adam Hug ed., 2016).

${ }^{11}$ See generally Albert O. Hirschman, Exit, Voice and Loyalty: Responses to Decline in Firms, Organizations, and STATES (1970).

${ }^{12}$ See generally Joseph H. H. Weiler, The European Community in Change: Exit, Voice and Loyalty, 3 IRISH STUD. INT'L AfF. 15 (1990).

${ }^{13} I d$. at 16.
} 
policy-making - in the knowledge that, once a policy was adopted, it would be difficult to renege upon later. The Community's stability was thus based on an equilibrium between the two values, with reduced exit options compensated by increasing state, and later citizen, control over the political process.

Weiler in 1990 already foresaw the weakness of this compromise. One was enforcement-what, ultimately, could the European court do, when national courts and governments simply refused to obey ? $^{14}$ One of his answers lay in judicial dialogue. Weiler's observation was that a key strength in the preliminary reference procedure was that national Courts ultimately executed judgementseven if they mostly followed the advice of the CJEU in doing so: "This takes care of the most dramatic weakness of that procedure, the ability of a Member State - in extremis - to dis-regard the strictures of the European Court. Under the 177 procedure this is not possible. A Member State - in our Western democracies - cannot disobey its own Courts." 15

This observation already points to some of the weaknesses of the Weiler thesis, at least if transported to today. At the level of outright exit, Weiler conceptualized the main risk not as departure of a Member State — which he assumed would trigger prohibitive cost—but the avoidance of treaty obligations. Brexit has shown us, however, not only that exit is a real possibility, but the impact of the exit option on political bargaining as well. Much of the EU's behavior in dealing with Brexit can be explained with reference to its contagion risks. The long-term legacy-one already observed in earlier treaty negotiations, such as over the Lisbon Treaty-could be the use of exit as a threat, to leverage better results under conditions of inter-state bargaining. ${ }^{16}$ As other international relations scholarship informs us, ${ }^{17}$ this risk is likely to be higher-and the resulting bargaining power stronger-for larger and more powerful Member States: Consider, for example, Greece's leverage when threatening a Euro exit, versus Germany's.

A more pressing problem may be not total but "selective" exit. Weiler conceptualized selective exit along Costa v. ENEL lines, that is, as ex-post dis-application of EU rules. EU policy now, though, includes numerous options for dis-applying EU law ex ante in the sense of governing through rules which do not offer the safeguards and qualities of normal EU law. Newer areas of EU action, such as EU economic governance, or asylum and immigration policy, heavily rely on a mixture of soft or international law-for example, the numerous memoranda and declarations regulating the relation between the $\mathrm{EU}$ and third states regarding irregular migration- ${ }^{18}$ and administrative enforcement-for example, the prominent role of Frontex in policing the Union's borders or of the EBA in the Banking Union. These mechanisms notoriously lack the certainty and precision of other forms of EU law, making them difficult to judicially supervise. ${ }^{19}$ In this sense, "selective exit" reappears not as an ad hoc dis-application of EU law, but as the danger that the EU may simply decide to leave traditional legal regulation behind in new areas of policy.

Finally, "selective exit" may occur at an institutional level: EU law can no longer take for granted a cooperative and mutually supportive relation with national courts and administrations. The irony of Weiler's quote above is that some EU governments have indeed become willing to disobey their own courts or, if not, to influence their composition. At the very least, the interplay between EU and national law has become politicized — the most recent example being the attempt

\footnotetext{
${ }^{14} I d$. at 21 .

${ }^{15} I d$. at 22 .

${ }^{16}$ See, e.g., Protocol on the Concerns of the Irish People on the Treaty of Lisbon, Mar. 2, 2013, 2013 O.J. (L 60) 131.

${ }^{17}$ See generally Sara Berglund, Prison or Voluntary Cooperation? The Possibility of Withdrawal from the European Union, 29 Scandinavian Pol. STUd. 147 (2006); Allan F. Tatham, Don't Mention Divorce at the Wedding, Darling!: EU Accession and Withdrawal after Lisbon, in EU LAW AFTER LISBON 128 (Andrea Biondi, Piet Eeckhout \& Stefanie Ripley eds., 2012).

${ }^{18}$ See, e.g., Juan Santos Vara, Soft International Agreements on Migration Cooperation with Third Countries: A Challenge to Democratic and Judicial Controls in the EU, in Constitutionalising The External Dimensions of EU Migration Policies IN Times of CRIsis 21 (Sergio Carrera, Juan Santos Vara \& Tineke Strik eds., 2019).

${ }^{19}$ See generally Mark Dawson, The Legal and Political Accountability Structure of Post-Crisis EU Economic Governance, 53 J. Common MKt. Stud. 976 (2015).
} 
of the Polish Attorney-General to question the constitutionality of Article 267 of the TFEU itself before the Polish Constitutional Tribunal. ${ }^{20}$ While EU law has therefore relied on objective national civil servants and cooperative judges — often socialized into a common legal elite $-{ }^{21}$ to provide EU law with domestic force, EU law faces the possibility of active resistance, at least within particular states.

What is significant about these three forms of exit is not just their cumulative effect per se, but their impact on the other elements of the Hirschman equation, namely voice and loyalty. As Weiler pointed out, the increase of voice is tied to the foreclosing of exit. More specifically, Member States have an incentive to increase opportunities for political participation in the Union where the Union is seen as a long-term project in which laws, once agreed, carry general application. But where this assumption is in question-where exit is no longer fore-closed-the incentives for voice are reduced. The cumulative effect of this is also the abandonment of loyalty, that is, of a long-term commitment to a particular organization even where its costs seem prohibitive at particular moments.

This could happen in different ways. One is a reduction of voice for all states, that is, that the general level of interest in improving and scrutinizing EU law of national parliaments, governments, and courts declines. Under this circumstance, the shadow of exit may not-as some commentators might have hoped following Brexit-spur the Union to democratize its decisionmaking procedures, but rather engender a degree of cynicism on the part of citizens and leaders that the EU system is worthy of reform. The recent ditching of the Union's Spitzenkandidaten system in favor of a consociational dividing of jobs between the main EU parties and decisionmakers may be a prophetic early example.

A second possibility, given the power imbalances between EU states discussed above, is that some states and populations may simply become more disengaged than others, that is, that voice is seen as a strategy realistically available to some states and populations but not others. We here have the risk of a downward spiral — as states, such as in the rule of law example above, engage in forms of subversion, they risk their political marginalization, which in turn loosens the bonds between their citizens and the larger European project. The consequence would be an abandonment of loyalty - that is, to turn the other EU Member States into Britain circa 2016: A state where even those in favor of the Union could argue for membership only on the basis of a simple weighing of costs and benefits.

\section{Towards a New Equilibrium?}

How can EU law avoid this bleak scenario? Thankfully, Hirschman's heuristic is not just a diagnostic but also a remedial tool. His categories thus provide three different levers of change. The first lever concerns exit. If the diagnosis above is correct, that is, that one of the main dangers the EU faces is a shifting of the Union's equilibrium from voice to exit, a first set of tools concern making exit more costly. Brexit has already produced an extensive debate regarding Article $50 .{ }^{22}$ One difficulty with that Article, however, is that exit costs become a matter of political bargaining. Exit negotiations - and citizen perception of those negotiations - have thus descended into a war of who is stronger than whom, with the EU side leveraging its size and market power, and the departing state using everything from hostage EU citizens to outstanding debt obligations as leverage in return. The reform of Article 50 could aim to make the costs of exit both higher, and clearer to citizens and

\footnotetext{
${ }^{20}$ Kacper Majewski, Will Poland, With Its Own Constitution Ablaze, Now Set Fire to EU Law?, VerfassungsBlog (Oct. 17, 2018), https://verfassungsblog.de/will-poland-with-its-own-constitution-ablaze-now-set-fire-to-eu-law/.

${ }^{21}$ See generally Antoine Vauchez, Brokering Europe: Euro-Lawyers and the Making of a Transnational POLITY (2015).

${ }^{22}$ See generally Closa, supra note 1.
} 
decision-makers in advance-for example by investing the structural debt of Member States, such as their pension and other budget obligations, into a debt instrument, to be automatically forfeited upon departure. ${ }^{23}$ The Union should also consider how the costs of departure from other EU structures and policies — such as the Eurozone or Schengen areas - will be born. In simple terms, one means of avoiding exit is to provide a broader range of EU structures with an exit price "built-in," some of which will emerge from market and other forces, and some of which would be legalized. The long-term hope is that Member States invest in EU structures in the knowledge that they are permanent structures.

More importantly, costs could attach to evasion as well as to exit outright. While the use of enhanced cooperation, for example, is regulated by a number of Treaty safeguards under Article 20 of the TEU, no such safeguards exist regarding agreements outside EU law-beyond the vague standards developed in Pringle, that such agreements must not undermine competences reserved to the Union. ${ }^{24}$ Similarly, the conceptualization of soft law as "soft" renders the Union's system of competence controls inapplicable, leaving few limits on its use as an alternative to traditional legislation. ${ }^{25}$ Increasing the costs of these forms of exit, or at least developing criteria as to when particular instruments may be used, is a further component in tackling the exit danger.

The second set of levers concern voice. States and citizens seem less likely to use any of the forms of exit discussed above if they see integration as forwarding their interests. This entails tackling two problems, each of which have been discussed elsewhere and are far too complex for this paper to do full justice. The first is a problem of inequality of voice. ${ }^{26}$ Ironically, the shift towards what political scientists have termed the "new inter-governmentalism," providing states with greater decision-making power over new areas of EU action, may strengthen inequalities of voice between states. ${ }^{27}$ To give one example, existing areas of differentiated integration, such as PESCO or the fiscal compact, are marked by their being initiatives of larger or core EU members, which others then felt compelled to join. Generalizing the Commission's power of initiative and tackling the increasing channeling of authority through institutions - such as the European Councilwhere large states dominate, is one crucial ingredient in tackling exit by managing voice.

A second problem concerns the capacity of EU law to represent changing political cleavages. Subversion may seem a simple ploy to evade EU obligations, but it also represents increasing disagreement about the values EU law should forward. Hirschman's categories were relatively value-neutral, that is, voice does not just include constructive feedback, but also rejection, and the transmission of information that would require drastic change in a given brand. The increasing prominence of populist parties in governments across the Union suggests that increasing voice must also mean allowing such parties to claim representation at the EU level. This speaks to a number of existing debates, including the discussion of "over-constitutionalization." 28 Populists have greater reason to seek exit, evasion, or subversion rather than voice if their policy preferences, for example greater restrictions on free movement or skepticism towards international trade, are rendered illegal by the Treaty structure. In this sense, increasing voice may also mean more radical

\footnotetext{
${ }^{23}$ Oliver Garner, Reforming Withdrawal and Opt-Outs from the European Union: A Dual-Constituent Perspective (2018).

${ }^{24}$ ECJ, Case C-370/12, Pringle v. Government of Ireland, ECLI:EU:C:2012:756, Judgment of 27 Nov. 2012, paras. 103-07.

${ }^{25}$ See generally Mark Dawson, Integration Through Soft Law: No Competence Needed? Juridical and Bio-Power in the Realm of Soft Law, in The Division of Competences Between the EU And the Member States (Sacha Garben \& Inge Govaere eds., 2017).

${ }^{26}$ See, e.g., Core-Periphery Relations in the European Union: Power and Conflict in a Dualist Political Economy (José M. Magone, Brigid Laffan \& Christian Schweiger eds., 2016).

${ }^{27}$ See generally Uwe Puetter, The European Council AND the Council: New InTergovernmentalism AND Institutional CHANGE (2014).

${ }^{28}$ See generally Dieter Grimm, The Constitution of European Democracy (2017).
} 
changes to the substantive structure of EU law, namely, opening it to the substantive arguments currently being advanced via domestic politics.

The last lever concerns the category we have dealt with least in this short contribution- the elusive notion of "loyalty." Put in simple terms, loyalty requires a degree of long-term attachment: Those that are loyal to brands maintain that attachment in spite of disapproval-temporally or materially - of elements of the brand. While it is not fashionable in contemporary social sciences to discuss issues of culture and identity, a more durable insurance policy against the dangers of exit is surely a stronger sense of cultural attachment between Europeans and EU law-such that exit, when threatened, will be socially resisted. As some recent research in the social sciences demonstrates, the rising tide of Euroscepticism has also mobilized a section of Europeans more aware of the precariousness of the EU project and, as a result, more willing to make personal sacrifices to protect it. ${ }^{29}$ In this sense, the key challenge of EU law-yet, at the same time, the most difficult to pin-down-is to cultivate the cultural connections between EU law and its subjects.

This last point illustrates the organic connection between loyalty and voice. A missing ingredient in Weiler's use of Hirschman was his attribution of voice largely to states. In doing so, he downplayed the trade-offs of contemporary EU governance shows between the voice of states and citizens. Increasing the former does not per se equate to the latter. At the same time, increasing the latter can preclude the exit of the former: If citizens grow more confident in the ability of EU law to articulate their collective goals, they are more likely to resist efforts on the parts of their states to exit EU law and the policies it seeks to forward. By enhancing the bonds of loyalty between citizens and the Union, exit options for states are foreclosed. The democratization and parliamentarization of the Union - seemingly the most complex and well-worn avenue of EU reform-is in this sense also the most direct means of tackling the exit threat. ${ }^{30}$

These represent schematic suggestions-enacting any of them would represent a major upheaval to the EU's legal order. Exit, evasion, and subversion, however, may require radical changes: Meeting them is necessary for the very survival of the EU legal order.

\footnotetext{
${ }^{29}$ See generally Theresa KuHn, Experiencing EUROPEAn InTEgration: TransNational Lives and EUROPEAN IDENTITY (2015).

${ }^{30}$ See generally Mark Dawson \& Floris de Witte, From Balance to Conflict: A New Constitution for the EU?, 22 EUR. L.J. 204 (2016).
}

Cite this article: Dawson M (2020). Coping with Exit, Evasion, and Subversion in EU Law. German Law Journal 21, 51-56. https://doi.org/10.1017/glj.2019.95 